\title{
Utilization of Triclosan to Enhance the Antibacterial Activities of Linen Fabric
}

\author{
R.A.A. Eid, T.M. Hassan", H.M. Fahmy ${ }^{* *}$, A. Amr ${ }^{* *}$ and \\ D.E. Nada \\ Faculty of Home Economic, Menoufia University,Menoufia \\ ${ }^{*}$ Faculty of Education, Helwan University and ${ }^{* *}$ Textile \\ Research Division, National Research Center, Dokki, Cairo, \\ Egypt.
}

O enhance the antibacterial activity of linen fabric against $S$.
aureus and $E$. coli., the fabric was treated with different
finishing baths containing Tinosan ${ }^{\circledR} \mathrm{CEL}(\mathrm{TC})$ at different conditions
of $\mathrm{pH}$, TC concentration, temperature and time. The results signified
that padding linen fabric samples in finishing bath of pH 5 containing
$10 \mathrm{~g} / \mathrm{L}$ aqueous solution of TC followed by drying the padded fabrics
at $85{ }^{\circ} \mathrm{C}$ for 5 min and curing at $130{ }^{\circ} \mathrm{C}$ for 3 min enhances the
antibacterial activity against $S$. aureus and $E$. coli of treated fabric
samples. Moreover, treating linen fabric samples with finishing baths
containing TC/amino silicone softener (SME)/crosslinker enhances
the nitrogen content, resiliency, yellowness indices and antibacterial
activities against $S$. aureus and $E$. coli, along with the reduction in
tensile strength and wettability of the treated fabrics. The antibacterial
activities of the linen samples treated with TC or TC/SME finishing
baths are durable up to 10 washing cycles whereas samples treated
with TC/SME/crosslinker finishing baths possess antibacterial
activities that are durable up to 25 washing cycles.

Textiles are well known as media for microorganisms growth such as bacteria and fungi. These microorganisms grow and multiply in the environment as moisture, nutrients and temperature are met ${ }^{(1)}$. The growth of microorganisms on textiles causes unpleasant effects for the textile itself and the wearer. These effects include the generation of unpleasant odor, stains onto fabric and a reduction in fabric mechanical strength ${ }^{(1)}$.

Triclosan is a broad-spectrum antimicrobial agent against many bacterial species. It is recognized since the 1960s and used in a wide range of industrial products such as hand soaps, surgical scrubs, shower gels, deodorants, healthcare handwashes, toothpastes and mouthwashes ${ }^{(2,3)}$. Triclosan inhibits the growth of the Gram positive and Gram negative bacteria through penetration the bacteria cell walls, causing the metabolites to leak out which disables other cell functions, hence preventing bacteria from functioning and reproducing ${ }^{(4)}$. Moreover, some researchers attribute the antibacterial activity of Triclosan for its action on inhibition of the fatty acid synthesis that is necessary for reproduction and building of cell membranes of bacteria ${ }^{(5-8)}$. 
Keeping in mind that background, the present work is undertaken with the view to establish the proper conditions to acquire linen fabric antibacterial activity as well as to provide the technical feasibility of combining the antibacterial finishing with other finishing treatments including easy care and soft finishing.

\section{Materials}

\section{Experimental}

Fabrics

The fabric used throughout this work was $100 \%$ linen fabric. The specifications of that fabric are shown in Table 1.

TABLE 1. Specification of the experimental fabric.

\begin{tabular}{|c|c|}
\hline Property & Specification \\
\hline Fabric structure & Plain $1 / 1$ \\
\hline Weight/area $\left(\mathrm{g} / \mathrm{m}^{2}\right)$ & 367 \\
\hline Thickness $(\mathrm{mm})$ & 0.6 \\
\hline Yellowness index & 29.45 \\
\hline
\end{tabular}

\section{Chemicals}

Tinosan $^{\circledR}$ CEL (TC), a mixture of 2,4,40-trichloro-2-hydroxy-diphenylether and polymeric encapsulating material, was used as an antibacterial agent and kindly supplied by Ciba, Switzerland. GL-300 ${ }^{\circledR}$, aqueous solution of dimethyloldihydroxyethylene urea (DMDHEU), Textchem Co, Egypt, was used. The commercial softeners: Basosoft ${ }^{\circledR}$ SWK (weakly cationic mixture of a fatty acid condensation product and polyethylene wax, supplied by Basf), Leomin ${ }^{\circledR}$ NI-ET (nonionic, hydrophilic, and supplied by Clariant) and Silicon-SLH ${ }^{\circledR}$ (micro emulsion silicon softener) (SME), supplied by Texchem Egypt CO., LTD) were used. Egyptol ${ }^{\circledR}$, Non-ionic wetting agent, supplied by the Egyptian Company for Starch and Yeast and Detergents, Egypt, was used. Sodium hydroxide, sodium silicate, sodium sulphate, acetic acid, sodium carbonate, boric acid, hydrochloric acid, sulphuric acid, ammonium chloride, ammonium phosphate, zinc sulphate, copper sulphate, potassium sulphate, magnesium chloride, sodium hypophosphite monohydrate (SHP), citric acid (CA), 1,2,3,4butanetetracarboxylic acid (BTCA), and hydrogen peroxide (35\%) were of laboratory grade chemicals.

\section{Fabric treatments}

Scouring and bleaching of linen fabric samples

The grey linen fabric was mill scoured by introducing the fabric into an aqueous bath containing $40 \mathrm{~g} /$ Lsodium hydroxide and 5 g/LLEgyptol ${ }^{\circledR}$ with adjusting the material-to-liquor ratio at 1:20 then the temperature was raised to $95{ }^{\circ} \mathrm{C}$ for $30 \mathrm{~min}$. The fabric was then washed several times with boiling water and finally with cold water. After scouring, the fabric was bleached using the

Egypt. J. Chem. 58, No. 2 (2015) 
following recipe: $\mathrm{H}_{2} \mathrm{O}_{2}, 10 \mathrm{~g} / \mathrm{L}$; sodium silicate, 4 g/L; NaOH, 2 g/L; Egyptol ${ }^{\circledR}, 2$ $\mathrm{g} / \mathrm{L}$; organic stabilizer, $2 \mathrm{~g} / \mathrm{L} ; \mathrm{MgSO}_{4}, 2 \mathrm{~g} / \mathrm{L}$, at $95^{\circ} \mathrm{C}$ for $45 \mathrm{~min}$. The fabric was washed several times with boiling water then with cold water and finally squeezed and dried at ambient conditions.

Easy care finishing of linen fabric samples

The finishing treatment was performed by padding linen fabric strips $(30 \times 30 \mathrm{~cm})$ twice, at wet pick-up $85 \%$, in finish formulations containing different concentrations of TC alone, TC /DMDHEU (using ammonium chloride, magnesium chloride or zinc sulphate as catalysts), TC /CA, or TC /BTCA (using SHP as a catalyst). To enhance linen fabrics performance as well as antibacterial properties of linen fabrics another finishing bathes containing SME/TC/ DMDHEU/ zinc sulphate or SME/TC/BTCA/SHP were employed. The padded fabrics were dried at $85{ }^{\circ} \mathrm{C}$ for 5 min followed by curing in Wenner Mathis AGCH8155 oven at specific temperature and time. The finished fabrics were then washed under occasional stirring, thoroughly rinsed and finally dried for testing.

\section{Testing and analysis}

- The nitrogen content (N\%) was determined according to Kjeldhal method ${ }^{(9)}$.

- The dry wrinkle recovery angle (WRA) was determined according to ASTM method D-1296-98 ${ }^{(10)}$.

- The tensile strength (TS) of the finished fabric sample was tested in the warp direction according to ASTM procedure D-2256-98 ${ }^{(11)}$.

- The wettability test (W) was carried out according to AATCC Test Method 39$1980^{(12)}$.

- The yellowness index (YI) were evaluated by using Color-Eye ${ }^{\circledR} 3100$ spectrophotometer supplied by SDL Inter, England, according to the Standard Test Method ASTM E313 ${ }^{(13)}$.

- Surface roughness (SR) was measured according to JIS 94 Standard, by Surface Roughness Measuring Instrument, SE $1700 \alpha^{(14)}$.

- The antimicrobial activity of control and finished linen fabrics was performed according to the disc diffusion method, AATCC Test Method 147-1988 ${ }^{(15)}$. The antibacterial activities of the untreated blank as well as finished fabrics were tested against the following bacteria :

Gram-positive bacteria: Staphylococcus aureus (SA).

Gram-negative bacteria: Escherichia coli (EC).

and expressed as zone of inhibition (ZI).

- Durability to wash was assessed by subjecting the fabric to 1,10 and 25 laundering cycles. Each laundering cycle consists of washing (10 $\mathrm{min}$ at 50 ${ }^{\circ} \mathrm{C}$ using $2 \mathrm{~g} /$ Lnonionic surfactant followed by rinsing and air drying at ambient conditions. 


\section{Results and Discussion}

Factors affecting the antibacterial activities of TC treated linen fabric samples $p H$

Figure 1 shows the antibacterial activities, expressed in the inhibition zones per mm, of different samples of linen fabrics upon their treating with aqueous solution of $10 \mathrm{~g} / \mathrm{LTC}$ at different pHs. It is clear that, for a given set of treatment conditions, the highest antibacterial properties of the treated fabric samples, against either $S$. aureus or $E$. coli, were achieved at $\mathrm{pH} 5$. Moreover, the results indicate that, at the same $\mathrm{pH}$, the TC treated fabrics possess higher resistance against $S$. aureus than $E$. coli.

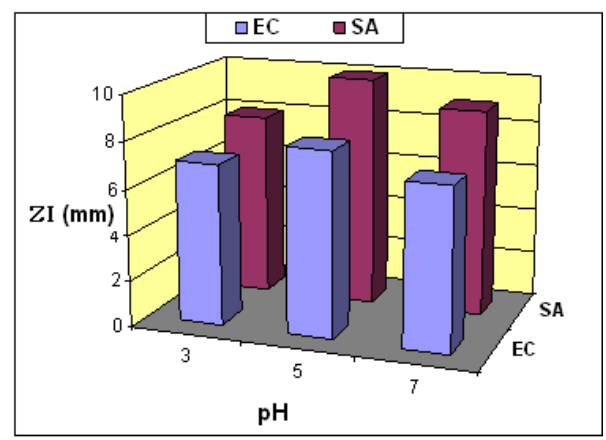

[TC], 10 g/L; wet pick up, $100 \%$; drying, $85{ }^{\circ} \mathrm{C} / 5 \mathrm{~min}$; curing, $120{ }^{\circ} \mathrm{C} / 3 \mathrm{~min}$. SA: S. aureus; EC: E. coli.

Fig. 1. Effect of $\mathrm{pH}$ on the antibacterial properties of treated linen fabrics.

Tinosan ${ }^{\circledR}$ CEL concentration

Figure 2 shows the antibacterial activities of linen fabric samples treated with different concentrations of $\mathrm{TC}$ aqueous solutions at $\mathrm{pH}$ 5. It is obvious that increasing the TC concentration, within the range studied, brings about an enhancement in the extent of the inhibition zones, against either $S$. aureus or $E$. coli. Furthermore, the results depict that the treated fabrics have higher inhibition zone for $S$. aureus than that for E. coli.

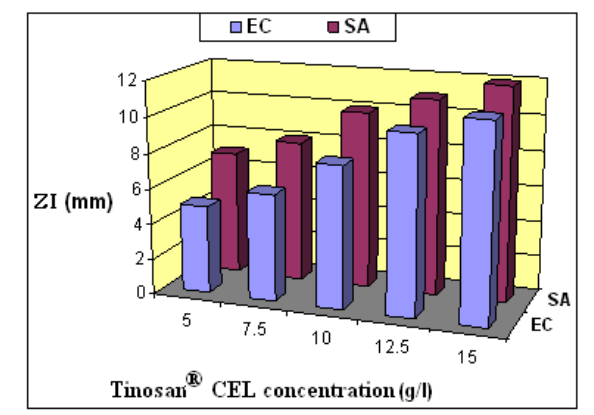

$\mathrm{pH}$, 5; wet pick up, $100 \%$; drying, $85^{\circ} \mathrm{C} / 5 \mathrm{~min}$; curing, $120{ }^{\circ} \mathrm{C} / 3$ min.

SA: S. aureus; EC: E. coli.

Fig. 2. Effect of TC concentration on the antibacterial properties of treated linen fabric samples.

Egypt. J. Chem. 58, No. 2 (2015) 


\section{Curing temperature}

The effect of curing temperature on the antibacterial activities of TC treated linen fabric samples is illustrated in Fig. 3. It is clear that, raising the curing temperature from $110{ }^{\circ} \mathrm{C}$ to $130{ }^{\circ} \mathrm{C}$ enhances the antibacterial activities of the treated fabrics, expressed in their inhibition zones. Further increasing of the curing temperatures, up to $160{ }^{\circ} \mathrm{C}$, results in marginal increasing in the inhibition zones.

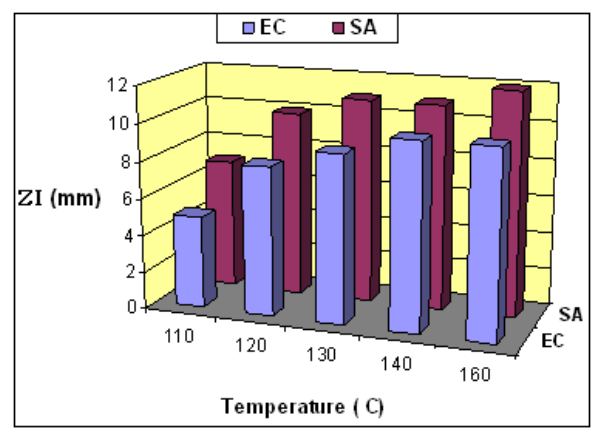

[TC], 10 g/L; pH, 5; wet pick up, 100\%; drying, $85^{\circ} \mathrm{C} / 5$ min; curing time, 3 min. SA: S. aureus; EC: E. coli.

Fig. 3. Effect of curing temperature on the antibacterial properties of treated linen fabric samples.

\section{Effect of curing time}

Figure 4 shows the effect of curing time on the antibacterial activities of TC treated linen fabric samples. It is clear that, increasing the curing time from 1 to 3 min is accompanied with an enhancement in the antibacterial activities, against $S$. aureus and E. coli, of the treated fabrics. Beyond 3 min, marginal increasing in the inhibition zones of the treated samples is noticed.

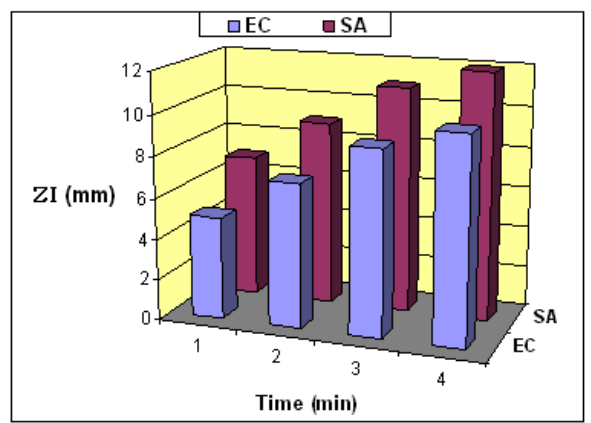

[TC], 10 g/L; pH, 5; wet pick up, $100 \%$; drying, $85^{\circ} \mathrm{C} / 5 \mathrm{~min}$; curing temp., $130{ }^{\circ} \mathrm{C}$.

SA: S. aureus; EC: E. coli.

Fig. 4. Effect of curing time on the antibacterial properties of the treated linen fabric samples. 
Incorporation of Tinosan ${ }^{\circledR}$ CEL in easy-care finishing

Easy-care finishing with DMDHEU

Catalyst type: Figure 5 shows the antibacterial activities of linen fabric samples treated with $10 \mathrm{~g} / \mathrm{LTC}$ and $50 \mathrm{~g} / \mathrm{Lof}$ DMDHEU using $5 \mathrm{~g} / \mathrm{Lof}$ ammonium chloride, magnesium chloride hexahydrate or zinc sulfate as catalysts. It is clear that verifying the catalyst type in the finishing bath affects the antibacterial activities of the treated fabrics and according to the catalyst type, the antibacterial activities of the treated fabrics against the aforementioned species of bacteria can be arranged in the following descending order:

$$
\mathrm{ZnSO}_{4}>\mathrm{MgCl}_{2} \cdot 6 \mathrm{H}_{2} \mathrm{O}>\mathrm{NH}_{4} \mathrm{Cl} \text {. }
$$

This order reflects the differences between these catalysts in their $\mathrm{H}^{+}$ donating ability and hence the extent of crosslinking which subsequently affect the fixation of the TC onto of the finished fabrics matrices. Furthermore, the relatively higher antibacterial properties of the treated samples on using the zinc sulfate as catalyst may be attributed to the deposition of the antibacterial zinc compounds ${ }^{\text {(16-19) }}$ onto and/or inside the fabric structure.

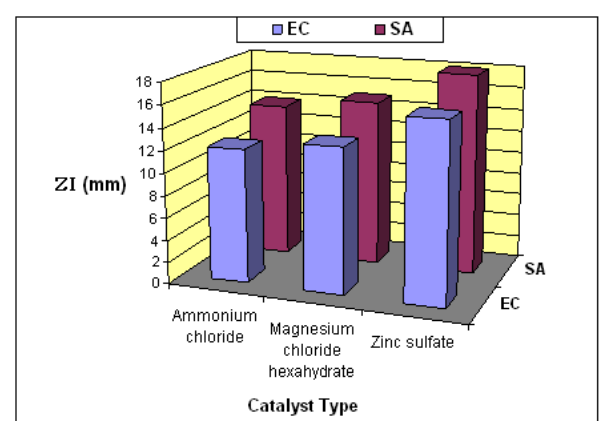

[TC], $10 \mathrm{~g} / \mathrm{L}$; [DMDHEU], $50 \mathrm{~g} / \mathrm{L}$; [catalyst], 5 g/L; wet pick up, 100\%; drying, $85{ }^{\circ} \mathrm{C} / 5$ min; curing, $160{ }^{\circ} \mathrm{C} / 3$ min. SA: S. aureus; EC: E. coli.

Fig. 5. Effect of catalyst type on the antibacterial activities of treated linen fabric samples.

Easy-care finishing with polycarboxylic acids

Table 2 shows the performance properties of linen samples crosslinked with either CA or BTCA in presence of $10 \mathrm{~g} / \mathrm{LTC}$. It is clear that: i) estrification of linen fabrics with CA or BTCA, in presence of $10 \mathrm{~g} / \mathrm{LTC}$, enhances the resiliency, yellowness, wettability and antibacterial activities but reduces the tensile strength of the treated samples, compared to the control sample, which is a direct consequence of esterification of the hydroxyl groups of linen cellulose with the carboxyl groups of the CA or BTCA along with the subsequent fixation of TC ${ }^{(20-22)}$; ii) the variation in the magnitudes of the aforementioned performance properties is governed by the polycarboxylic acid type reflecting the differences between BTCA and CA in their reactivity, activation energy, functionality, structure, thermal stability level, extent of esterification, and number and length of crosslinks ${ }^{(23)}$.

Egypt. J. Chem. 58, No. 2 (2015) 
TABLE 2. Effect of polycarboxylic acid type on the performance properties of the treated linen fabrics.

\begin{tabular}{|l|l|l|l|l|l|l|}
\hline $\begin{array}{l}\text { Polycarboxylic } \\
\text { acid type }\end{array}$ & $\begin{array}{l}\text { WRA } \\
(\mathbf{w}+\mathbf{f})^{\circ}\end{array}$ & $\begin{array}{l}\text { TS } \\
(\mathbf{K g})\end{array}$ & $\begin{array}{l}\text { W } \\
(\mathbf{S})\end{array}$ & YI & \multicolumn{2}{|l|}{ ZI (mm) } \\
\cline { 5 - 7 } & & & & & $\boldsymbol{E C}$ & SA \\
\hline Untreated & 86 & 83.2 & 1.17 & 17.02 & - & - \\
\hline Control & 82 & 81.1 & 1.56 & 18.83 & 10 & 13 \\
\hline CA & 129 & 49.9 & 1.44 & 20.94 & 13 & 15 \\
\hline BTCA & 143 & 47.7 & 1.26 & 19.25 & 13 & 16 \\
\hline
\end{tabular}

[TC], 10 g/L; polycarboxylic acid/SHP molar ratio, 1; wet pick up, $100 \%$; drying, $85^{\circ} \mathrm{C} / 5$ min; curing, $180^{\circ} \mathrm{C} / 90 \mathrm{sec}$. Control, sample treated only with $10 \mathrm{~g} / \mathrm{L}$ TC.

\section{Incorporation of Tinosan ${ }^{\circledR}$ CEL in soft finishing}

At this step of the work, both the antibacterial as well as soft finishing of linen fabric samples is combined and the antibacterial activities of the treated fabrics are monitored in Fig. 6. It is clear that none of the aforementioned softeners imparts antibacterial properties to the treated fabrics. Furthermore, incorporation of Leomin $^{\circledR}$ NI or Basosoft ${ }^{\circledR}$ SWK softener in the finishing bathes containing TC reduces the antibacterial properties of the treated samples, compared to the control sample, with different extents, whereas Silicon ${ }^{\circledR}$ SLH (SME) enhances that properties reflecting the differences between these hand modifiers in chemical composition, functionality, ionic nature, location and extent of surface modification, film forming properties, compatibility with other ingredients, mode of interaction, durability to wash as well as thermal stability ${ }^{(24)}$. Meanwhile, the enhancement in the antibacterial properties achieved by SME may be attributed to the more fixation of the TC encapsulated by that softener on the fabric surface.

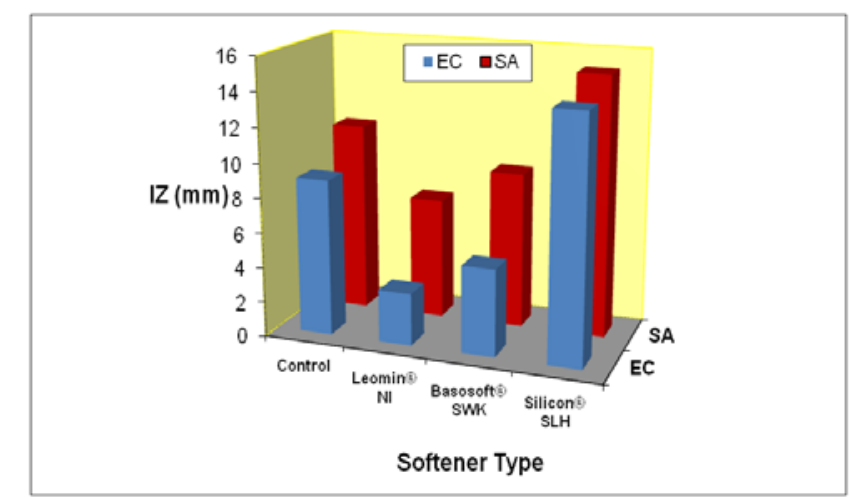

[softener], 20 g/L; pH, 5; wet pick up, 100\%; drying, $85^{\circ} \mathrm{C} / 5 \mathrm{~min}$; curing, $130{ }^{\circ} \mathrm{C} / 3 \mathrm{~min}$. Control, linen sample treated with TC in absence of any of softeners. SA: S. aureus; EC: E. coli.

Fig. 6. Effect of softener type on the antibacterial properties of treated linen fabrics. 


\section{Incorporation of Tinosan ${ }^{\circledR}$ CEL in combined soft and easy care finishing}

Table 3 shows the effect of the combined soft and easy care finishing on the performance properties of TC treated linen fabrics. It is clear that incorporation of SME in the finishing bathes containing TC or TC /crosslinker, regardless of the crosslinker type, brings about an enhancement in the nitrogen content, resiliency, and softness along with the reduction in tensile strength, yellowness and wettability of the treated fabrics. The enhancement in such properties may be due to: i) deposition of a softener film onto and /or within the linen structure thereby softening the fibers and thus decreasing interfibre and interyarn friction, and ii) formation of interfibre and interyarn bonds ${ }^{(24)}$. Moreover, it is clear from Table 3 that despite of the remarkable enhancement in the resiliency as well as softness properties, resulting from presence of SME in the finishing bathes, the wettabilities of the treated linen fabrics were impaired significantly. Moreover, finishing the fabrics with polycarboxylic acids may slightly decrease that drawback in wettability which could be related to the ester crosslinking of the cellulosic hydroxyl groups with the carboxylic groups of either CA or BTCA leaving single ended carboxyl groups bound to the fabric structure ${ }^{(25)}$.

TABLE 3. Effect of the combined soft and easy care finishing on the performance properties of TC treated linen fabrics.

\begin{tabular}{|c|c|c|c|c|c|c|c|c|}
\hline \multirow{2}{*}{ Treatment bath } & \multirow[t]{2}{*}{ N\% } & \multirow{2}{*}{$\begin{array}{c}\text { WRA } \\
(w+f)^{\circ}\end{array}$} & \multirow{2}{*}{$\begin{array}{c}\text { TS } \\
(\mathrm{Kg})\end{array}$} & \multirow[t]{2}{*}{ SR } & \multirow{2}{*}{$\begin{array}{l}W \\
\text { (S) }\end{array}$} & \multirow[t]{2}{*}{ YI } & \multicolumn{2}{|c|}{ ZI (mm) } \\
\hline & & & & & & & $E C$ & $E C$ \\
\hline Untreated & 0.0601 & 86 & 83.2 & 20.3 & 1.17 & 17.02 & - & - \\
\hline$(\mathrm{TC})^{\mathrm{a}}$ & 0.0601 & 81 & 81.7 & 20.6 & 1.66 & 18.12 & 10 & 12 \\
\hline$(\mathrm{SME} / \mathrm{TC})^{\mathrm{b}}$ & 0.0945 & 117 & 79.3 & 18.1 & 27 & 17.43 & 13 & 15 \\
\hline (DMDHEU/SME/TC) $^{\mathrm{c}}$ & 0.3189 & 169 & 71.2 & 18.9 & 29 & 19.41 & 18 & 21 \\
\hline$\left(_{\text {CA/SME/TC })^{d}}\right.$ & 0.0871 & 171 & 43.1 & 18.5 & 21 & 20.53 & 16 & 18 \\
\hline$(\text { BTCA/SME/TC })^{\mathrm{e}}$ & 0.1052 & 183 & 38.8 & 18.9 & 20 & 19.74 & 16 & 19 \\
\hline
\end{tabular}

a Test fabric padded in aqueous solution containing $10 \mathrm{~g} / \mathrm{L}$ TC. pH, 5; wet pick up, 100\%; drying, $85^{\circ} \mathrm{C} / 5 \mathrm{~min}$; curing, $160^{\circ} \mathrm{C} / 3 \mathrm{~min}$.

b Test fabric padded in aqueous solution containing $10 \mathrm{~g} / \mathrm{L} \mathrm{TC}$ and $20 \mathrm{~g} / \mathrm{L} \mathrm{SME.} \mathrm{pH,} \mathrm{5;} \mathrm{wet} \mathrm{pick}$ up, $100 \%$; drying, $85^{\circ} \mathrm{C} / 5 \mathrm{~min}$; curing, $130^{\circ} \mathrm{C} / 3 \mathrm{~min}$.

c Test fabric padded in aqueous solution containing $10 \mathrm{~g} / \mathrm{L}$ TC, $20 \mathrm{~g} / \mathrm{L}$ SME, $50 \mathrm{~g} / \mathrm{L}$ DMDHEU and 5 g/L $\mathrm{ZnSO}_{4}$. Wet pick up, 100\%; drying; $85^{\circ} \mathrm{C} / 5$ min; curing, $160{ }^{\circ} \mathrm{C} / 3$ min.

d Test fabric padded in aqueous solution containing $10 \mathrm{~g} / \mathrm{L}$ TC, 20 g/LSME, 80 g/L CA and SHP (CA/SHP molar ratio is equal1). Wet pick up, 100\%; drying, $85^{\circ} \mathrm{C} / 5 \mathrm{~min}$; curing, $180^{\circ} \mathrm{C} / 90 \mathrm{sec}$.

${ }^{\mathbf{e}}$ Test fabric padded in aqueous solution containing $10 \mathrm{~g} / \mathrm{L}$ TC, $20 \mathrm{~g} / \mathrm{LSME}, 80 \mathrm{~g} / \mathrm{L}$ BTCA and SHP (BTCA/SHP molar ratio is equal1). Wet pick up, $100 \%$; drying, $85^{\circ} \mathrm{C} / 5 \mathrm{~min}$; curing, $180{ }^{\circ} \mathrm{C} / 90$ sec.

On the other hand, Table 3 depicts the effect of the finishing bath ingredients on the antibacterial properties of TC treated linen fabrics. It is clear that: i) incorporation of SME in the finishing baths containing TC or TC/crosslinker,

Egypt. J. Chem. 58, No. 2 (2015) 
regardless of the crosslinker type, brings about an enhancement in the antibacterial properties of TC treated linen fabrics, and ii) incorporation of DMDHEU or polycarboxylic acids as crosslinker in the finishing baths enhances significantly the antibacterial properties of treated fabrics. These results reflect the role of SME as well as the crosslinker in fixation of TC onto the finished fabrics matrices. Moreover, besides the advantage of SME softener in encapsulation the TC, it imparts the fabric surface with hydrophobic characters that form unsuitable environment for the bacterial growth, thereby enhances the antibacterial properties of the treated samples.

\section{Durability to wash}

Table 4 shows the durability of antibacterial properties of different linen samples, treated with different finishing bathes, after 1, 10 and 25 washing cycles. It is clear that in case of finishing bathes a, b and c, the antibacterial activities of finished linen samples decrease after the first 10 washing cycles then they completely disappear after 25 washing cycles indicating that TC is not firmly bound to the cellulose structure as it has no reactive groups able to attach chemically the fabric structure ${ }^{(5,26)}$. Meanwhile, the antibacterial activity of the linen sample finished through treatment $d$, e and f shows gradual little drops after 10 and 25 washing cycles reflecting the role of the crosslinkers, regardless their type, in fixation the encapsulated TC onto the fabrics matrices.

TABLE 4. Effect of repeated washing on the antibacterial properties of Triclosan containing finished linen fabrics.

\begin{tabular}{|c|c|c|c|c|c|c|}
\hline \multirow{4}{*}{ Treatment bath } & \multicolumn{6}{|c|}{ Washing cycles } \\
\hline & \multicolumn{2}{|c|}{1} & \multicolumn{2}{|c|}{10} & \multicolumn{2}{|c|}{25} \\
\hline & \multicolumn{6}{|c|}{ ZI (mm) } \\
\hline & $E C$ & $S A$ & $E C$ & $S A$ & $E C$ & $S A$ \\
\hline$(\mathrm{TC})^{\mathrm{a}}$ & 9 & 11 & 2 & 4 & - & - \\
\hline (TC/SME) $^{\mathrm{b}}$ & 11 & 13 & 5 & 6 & - & - \\
\hline (TC/SME/DMDHEU) $^{\mathrm{C}}$ & 18 & 21 & 16 & 19 & 13 & 16 \\
\hline$(\text { TC/SME/CA })^{d}$ & 16 & 18 & 13 & 15 & 9 & 11 \\
\hline (TC/SME/BTCA) $^{\mathrm{e}}$ & 16 & 19 & 14 & 17 & 10 & 13 \\
\hline
\end{tabular}

${ }^{a}$ Test fabric padded in aqueous solution containing $10 \mathrm{~g} / \mathrm{L}$ TC. pH, 5; wet pick up, 100\%; drying, $85^{\circ} \mathrm{C} / 5 \mathrm{~min}$; curing, $130^{\circ} \mathrm{C} / 3 \mathrm{~min}$.

b Test fabric padded in aqueous solution containing $10 \mathrm{~g} / \mathrm{L} \mathrm{TC}$ and $20 \mathrm{~g} / \mathrm{L} \mathrm{SME.} \mathrm{pH,} \mathrm{5;} \mathrm{wet}$ pick up, $100 \%$; drying, $85{ }^{\circ} \mathrm{C} / 5 \mathrm{~min}$; curing, $130{ }^{\circ} \mathrm{C} / 3 \mathrm{~min}$.

c Test fabric padded in aqueous solution containing $10 \mathrm{~g} / \mathrm{L}$ TC, $20 \mathrm{~g} / \mathrm{L}$ SME, 50 g/LDMDHEU and 5 g/L $\mathrm{ZnSO}_{4}$. Wet pick up, 100\%; drying; $85^{\circ} \mathrm{C} / 5$ min; curing, 160 ${ }^{\circ} \mathrm{C} / 3 \mathrm{~min}$.

d Test fabric padded in aqueous solution containing 10 g/L TC, 20 g/LSME, 80 g/L CA and SHP (CA/SHP molar ratio is equal1). Wet pick up, 100\%; drying, $85{ }^{\circ} \mathrm{C} / 5 \mathrm{~min}$; curing, $180^{\circ} \mathrm{C} / 90 \mathrm{sec}$.

${ }^{\mathbf{e}}$ Test fabric padded in aqueous solution containing 10 g/L TC, 20 g/L SME, 80 g/L BTCA and SHP (BTCA/SHP molar ratio is equal1). Wet pick up, $100 \%$; drying, $85^{\circ} \mathrm{C} / 5 \mathrm{~min}$; curing, $180^{\circ} \mathrm{C} / 90 \mathrm{sec}$. 


\section{Conclusions}

The experimental results signified that:

i) padding linen fabrics in $10 \%$ aqueous solution of $\mathrm{TC}$ at $\mathrm{pH} 5$ followed by drying the padded fabrics at $85^{\circ} \mathrm{C}$ for 5 min and curing at $130{ }^{\circ} \mathrm{C}$ for 3 min imparts antibacterial properties for the treated fabrics,

ii) in finishing baths containing $50 \mathrm{~g} / \mathrm{L}$ of DMDHEU and $10 \mathrm{~g} / \mathrm{L} \mathrm{TC}$, the catalyst type affect the antibacterial activities of the treated fabrics and according to the catalyst type, the antibacterial activities of the treated fabrics can be arranged in the following descending order: $\mathrm{ZnSO}_{4}>\mathrm{MgCl}_{2} .6 \mathrm{H}_{2} \mathrm{O}>\mathrm{NH}_{4} \mathrm{Cl}$,

iii) estrification of linen fabrics with CA or BTCA, in presence of $10 \mathrm{~g} / \mathrm{L}$ TC, enhances the resiliency, yellowness, wettability and antibacterial activities but reduces the tensile strength of the treated samples, compared to the control sample,

iv) the variation in the magnitudes of the aforementioned performance properties is governed by the polycarboxylic acid type,

v) incorporation of SME of in the finishing bathes containing either TC or TC /crosslinker, regardless of the crosslinker or the catalyst type, enhances the nitrogen content, resiliency, softness, yellowness and antibacterial activities along with the reduction in tensile strength and wettability of the treated fabrics, and

vi) the antibacterial activities of the linen samples treated with TC or TC/SME finishing bathes finishing bathes are durable up to 10 washing cycles whereas samples treated with TC/SME/DMDHEU/ZnSO 4 , TC/SME/CA/SHP or TC/SME/BTCA/SHP finishing bathes possess antibacterial activities that are durable up to 25 washing cycles with little drops in their extents.

\section{References}

1. Purwar, R. and Joshi, M., Recent developments in antimicrobial finishing of textiles-A review, AATCC Review, 4, 22-26 (2004).

2. Jones, R.D., Jampani, H.B., Newman, J.L. and Lee, A.S., Triclosan: A review of effectiveness and safety in health care settings. Am. J. Infect. Contr. 28, 184-196 (2000).

3. Bhargava, H.N. and Leonard, P.A., Triclosan: Applications and safety. Am. J. Infect. Contr. 24, 209-218 (1996).

4. Schindler, W.D. and Hauser, P.J., Chemical Finishing of Textiles, Chap. 15, (Cambridge: Woodhead Publishing Limited, 165 (2004).

5. Ibrahim, N.A., Hashem, M., El-Sayed, W.A., El-Husseiny, S. and El-Enany, E., Enhancing antibacterial properties of dyed and finished cotton/polyester fabrics. AATCC Review, February, 56-64 (2010).

Egypt. J. Chem. 58, No. 2 (2015) 
6. Levy, C.W., Roujeinikova, A., Sedelnikova, S., Baker, P.J., Stuitje, A.R., Slabas, A.R., Rice, D.W. and Rafferty, J.B., Molecular basis of triclosan activity, Nature, 398, 383-384 (1999).

7. Anand, S. et al., Medical Textiles and Biomaterials for Health Care, Woodhead Publishing Ltd., Cambridge, England (2006).

8. Rastogi, S., Krongaard, T. and Jensen, G., Antibacterial Compounds in Clothing Articles, National Environmental Research Institute, Danish EPA, Roskilde, Denmark, (2003).

9. Vogel, A. I. Elementary Practical Organic Chemistry, in Quantitative Organic Analysis. London, Longman Group LTD, 652 (1975).

10. ASTM method D-1296-98.

11. ASTM procedure D-2256-98.

12. AATCC Test Method 39-1980.

13. ASTM E313.

14. JIS 94 Standard

15. Australian-New Zealand Standard AS/NZS 4399-1996: Sun Protective Clothing Evaluation and Classification.

16. Ibrahim, N. A., Bayazeed, A., Refai, R. and Hebeish, A., Some basics of easy-care cotton finishing. American Dyestuff Reporter, 75(5), 13-21 (1986).

17. Fahmy, H.M., Physico-mechanical characteristics of sizing agents mixtures and their applications in textile processing. MSc Thesis, Cairo, Helwan University (1994).

18. Nakashima, T., Sakagami, Y., Ito, H. and Matsuo, M., Antibacterial activity of cellulose fabrics modified with metallic salts. Textil. Res. J. 71, 688-694 (2001).

19. Gaffar, M.A., Some studies on the modification and application of polyvinyl alcohol, MSc Thesis, Cairo University, Cairo (1996).

20. Welch, C.M. and Peters, J.G., Durable press finishes using citric and tartaric acid with methyl hydrogen silicone. Textile Chemist and Colorist \& American Dyestuff Reporter, 3, 55-60 (1999). 
21. Ibrahim, N.A., Abo-Shosha, M.H., El-Nagdy, E.I. and Gaffar, M.A., Eco-friendly durable press finishing of cellulose-containing fabrics. Journal of Applied Polymer Science, 84, 2243-2253(2002).

22. Fahmy, H.M. and Abdel-Halim, E.S., Utilization of poly(N-vinyl-2-pyrrolidone) to enhance the performance properties as well as UV protection of ester crosslinked cotton fabrics. Journal of Industrial Textiles, 40 (2), (2010).

23. Fahmy, H.M., Enhancing some performance properties of ester crosslinked cotton fabric by pre-quaternization. Egyptian Journal of Chemistry, 47(6), 627-639 (2004).

24. Hashem, M.M. and Ibrahim, N.A., Response of linen fabric to finishing treatments. Journal of the Textile Association, Nov.-Dec. 189 - 194 (2002).

25. Moustafa M.G. Fouda and Fahmy, H.M., Multifunctional finish and cotton cellulose fabric. Carbohydrate Polymers, 86, 625- 629 (2011).

26. Abo-Shosha, M.H., Hashem, A.M., El-Hosamy, M.B. and El-Nagar, A.H., A leaching type antibacterial agent in the easy-care finishing of knitted cotton fabric. Journal of Industrial Textiles, 37(1), 55-77 (2007).

(Received 2 /3/2015;

accepted 23/3/2015) 


\section{استخدام الترايكلوزان لتعزيز خواص أقمشه الكتان ضد البكتريا

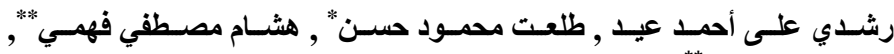

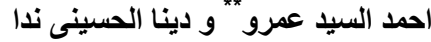

كلية الاقتصاد المنزلي - جامعة المنوفية , *كلية التربيه - جامعة حلوان و** قسم ابحاث النسيج ـ المركز القومى للبحوث ـ ـ القاهرة ـ مصر.

لتعزيز خواص أقمشه الكتان ضد البكتريا تم معالجة هذه الأقشة فى حمامات

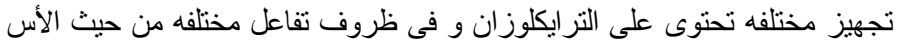

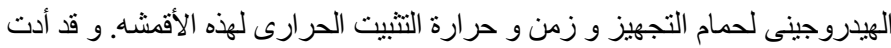
التجارب العمليه الى النتائج الأتيه:

1- يؤدى امر ار أقمشه الكتان فى حمام تجهيز مائى ذات أس هيدروجينى 5 و يحتوى 10 ئرى

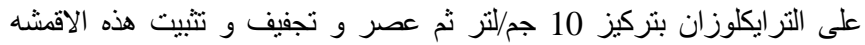

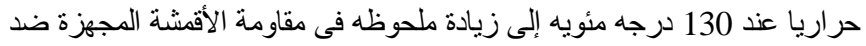
نو على البكتريا

2- يؤدى معاملة أقشه الكتان فى حمامات تجهيز مختلفه تحتوى على الترايكلوزان/

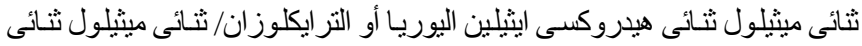

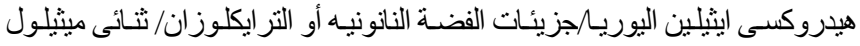

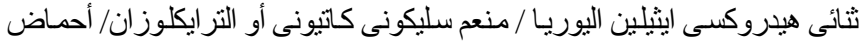

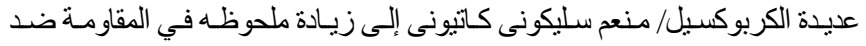

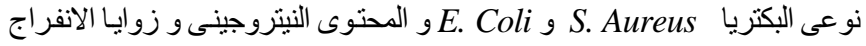

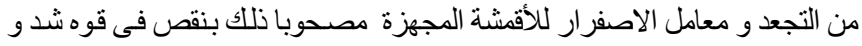
إبتلالية هذه الأقمشة.

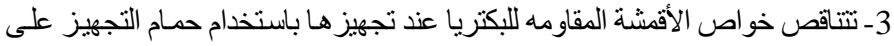

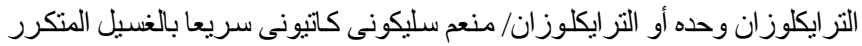

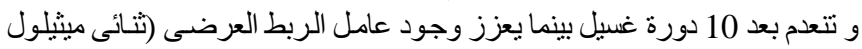
ثنائى هيدروكسى ايثيلين اليوريا أو أحماض وندئ عديدة الكربوكسيل) في حمام التجهيز من هذه الخو اصنى حتى بعد 25 دورة غسيل. 